\title{
Efficient in vitro Clonal Propagation of Muscari neglectum Guss. Ex. Ten Using Thidiazuron- $\alpha$ Naphthalene Acetic Acid
}

\author{
Çiğdem Alev Özel ${ }^{1^{*}}$, Fatma Ünal ${ }^{2}$
}

${ }^{I}$ Department of Biology Education, Faculty of Gazi Education, Gazi University, Teknikokullar, 06500 Ankara, Turkey ${ }^{2}$ Department of Biology, Faculty of Science, Gazi University, Teknikokullar, 06500 Ankara, Turkey

\begin{tabular}{l}
\hline A R T I C L E I N F O \\
\hline Article history: \\
Received 09 June 2016 \\
Accepted 10 November 2016 \\
Available online, ISSN: 2148-127X \\
\hline Keywords: \\
Acclimization \\
Micropropagation \\
Bulbous Plant \\
Regeneration \\
Rooting
\end{tabular}

*Corresponding Author:

E-mail: cigdemozel@gmail.com \begin{abstract}
A B S T R A C T
Muscari neglectum Guss. Ex Ten, is an ornamental, herbaceous perennial plant species that grows in the Mediterranean countries with attractive and scented blue-colored flowers. The plant has low seed output, seed dormancy, low germination and propagation rates. This study aimed to develop a reliable microclonal propagation protocol for $M$. neglectum using TDZ (Thidiazuron)-NAA ( $\alpha$ Naphthalene acetic acid) to induce bulblets, roots, and acclimatization of the regenerated bulblets. Maximum number of bulblets per explant $(8.25 \pm 0.05)$ was noted on MS medium containing $0.0454 \mu \mathrm{M}$ TDZ-5.37 $\mu \mathrm{M}$ NAA. The bulblets regenerated in each type of culture medium were very vigorous, and acclimatized easily following rooting on a subculture. Here we show that this protocol is a useful clonal micropropagation system for this important ornamental plant.
\end{abstract}

\section{Introduction}

Muscari neglectum Guss. Ex Ten; or neglectum grape hyacinth belonging to the genus Muscari subgenus Botryanthus (Kunth) Rouy (Davis and Stuart, 1984), is an ornamental, herbaceous perennial widespread polymorphic plant species. It grows up to $2300 \mathrm{~m}$ altitude in the Mediterranean countries of the Eastern Europe, the North Africa and the Western Asia (Doussi and Thanos, 2002). It has lanceolate leaves about $40 \mathrm{~cm}$ in length and emerges in autumn, with 4-6 emerged leaves growing on the bulbs. It has attractive and scented blue-colored flowers, which are commonly used as a dressing and seasoning in Mediterranean cuisine. They are also eaten fresh or pickled, and have various nutritive and medicinal properties (Lim, 2014).

The uppermost flowers are usually light blue, small and sterile; whereas, the flowers below are blackish blue and white recurved teeth; which, bloom in spring. Its bulbs are used for its diuretic and stimulant properties. These plants are highly important medicinally, and their propagation could help in easy extraction of compounds for pharmaceutical industry (Nasrabadi et al., 2013). The root is anti-inflammatory, antiallergic and aphrodisiac with pectoral stimulating characteristics (Usher, 1974).

The plant has low seed output, seed dormancy and low germination capacity (Karamian et al., 2011). First tissue culture study on Muscari spp. was carried out by Saniewski and Pytlewski (1979) using leaves and inflorescence stalk of $M$. comosum. It was followed by somatic embryogenesis from leaf-derived calli by Moris and Nakano (2004). Protoplast culture-based plantlet regeneration has also been reported by Nakano et al. (2005) and Karamian et al. (2011). However, sustainable micropropagation of $M$. neglectum is elusive.

Wild flora is generally not exploited because of the lack of funds. Among these plants, many have high potential for landscaping and could be used as ornamental plants in parks and on roadsides (Jaime et al., 2016). One of these amazing plants $M$. neglectum is very difficult to propagate using conventional techniques. Moreover, their multiplication is largely affected by environmental biotic and abiotic stresses. A review of regeneration methods reported above suggest that there is a need to develop reliable microclonal propagation protocols for $M$. neglectum. The objectives of the study was to to develop a protocol for micropropagation, rooting and acclimatisation of Muscari neglectum using bulb twin scales as explants on MS medium containing different concentrations of TDZ (Thidiazuron)-NAA ( $\alpha$ Naphthalene acetic acid) to establish a rapid and efficient in vitro propagation system. In practical terms, these microclonal propagation results will provide a useful system for a wide range of biotechnological applications for this plant species.

\section{Materials and methods}

M. neglectum bulblets were collected from Doğandede Tepesi (Beypazarı, Ankara, Turkey); where they grow in wild. The plants were identified at the department of Biology, section plant taxonomy, Gazi University, Ankara, Turkey. 
Bulblets were stored in a dark, cool and dry place for 4 weeks. Thereafter, they were subjected to surface sterilisation using $80 \%$ of commercial bleach $(4 \% \mathrm{NaOCl}$, Ace -Turkey) for 20 minutes. Each $100 \mathrm{ml}$ of bleach was supplemented with $1 \mathrm{ml}(\mathrm{v} / \mathrm{v})$ of Tween 20 as surfactant. Sterilized experimental materials were rinsed 5 times for 3 minutes each using bidistilled sterilized water. The bulblets were sliced into four upside down vertical slices followed by separating twin bulb scales from them (slices). Each explant was attached by a thin binding segment at the basal plate. Each explant was treated with $1 \%(\mathrm{v} / \mathrm{v})$ of Plant Preservation Mixture (PPM) for 2 hours. Thereafter, these bulb scales were cultured on MS medium (Murashige and Skoog, 1962) supplemented with $7.0 \mathrm{~g} / \mathrm{l}$ of Plant Cell Culture Tested type A agar (SigmaAldrich, Germany) and $30 \mathrm{~g} / \mathrm{l}$ of sucrose (Sigma-Aldrich, Germany) for 4 days to screen them against any possible microorganism-based contaminations. All cultures were autoclaved at $121^{\circ} \mathrm{C}, 104 \mathrm{kPa}$ for 20 minutes after adjusting their $\mathrm{pH}$ to $5.6-5.8$.

The screened bulb scales were cultured on MS medium containing $0.0454,0.06811$, or $0.0908 \mu \mathrm{M}$ TDZ and $2.685,5.37$, or $10.74 \mu \mathrm{M}$ NAA.All explants were incubated at $24 \pm 1^{\circ} \mathrm{C}$ under Philips day light lamps (TLD $36 \mathrm{~W} / 54$, Hungary) with a $16 \mathrm{~h}$ light $(35 \mu \mathrm{mol}$ photons $\mathrm{m}$ ${ }^{2} \mathrm{~s}^{-1}$ ) photoperiod for 8 weeks for microclonal propagation.

All rooted bulblets were washed in running tap water to remove the solidified agar medium adhering to the roots. Then, the bulblets were transferred to pots containing leaf compost and were uprooted after eight weeks. Leaf compost was made from local environmentfriendly green and dried leaf material. It had low bulk density of $0.3 \mathrm{mg} \mathrm{m}^{-3}$. Furthermore, it had a $\mathrm{pH}$ of 6.5 and EC of $0.3 \mathrm{dS} \mathrm{m}^{-1}$, with porosity of $\sim 70 \% \mathrm{v} / \mathrm{w}$ that allows high water absorption.

All pots containing Muscari bulblets were carefully covered with transparent polyethylene bags (110 guage) to maintain high relative humidity in the micro climate. Pots were kept at room temperature $\left(24^{\circ} \mathrm{C}\right)$ conditions using Sanyo versatile plant growth chamber $\theta$. Following 12 days of acclimatization, transparent bags were perforated to allow the plants to acclimatise slowly to the environment. Once the plants were hardened, the polythene bags were removed completely.
Each treatment had 4 replicates, each containing 4 explants ( 4 explants $\times 4$ replicates $=16$ explants $)$, and repeated twice. All developing buds with laminal shoots were counted as bulblets and the rest of them were counted as bulblet buds at the time of recording data, which was taken after 8 weeks of culture, or as described in the suitable section. The data were subjected to GLM univariate analysis using IBM SPSS 20.0 for windows statistical software. Arcsine transformation was performed for all data in percentages (Snedecor and Cochran, 1967) before subjecting them to the statistical analysis. Post-hoc tests were defined at $\mathrm{P} \leq 0.05$ using appropriate methods as described in the footnotes at the bottom of each table.

\section{Results}

Bulblet Initiation and Multiplication Using Twin Scale Explants in MS Medium Containing TDZ-NAA

In vitro bulblet regeneration was noted on MS medium containing different concentrations of TDZNAA. The data was noted after eight weeks of culture, when most of the explants had stopped regenerating new bulblet buds. The evaluations of the results showed that the percentage of bulb buds per explant induction ranged from $8.33 \pm 0.013$ to $16.67 \pm 0.08$. These results were not observed in media supplemented with $0.06811 \mu \mathrm{M}$ TDZ $2.685 \mu \mathrm{M}$ NAA, $0.0908 \mu \mathrm{M}$ TDZ - $5.37 \mu \mathrm{M}$ NAA, $0.0908 \mu \mathrm{M}$ TDZ - $10.74 \mu \mathrm{M}$ NAA and control MS medium (Table 1). Maximum number of $3.83 \pm 0.01 \mathrm{bulb}$ buds were noted on MS medium containing $0.0908 \mu \mathrm{M}$ TDZ - $2.685 \mu \mathrm{M}$ NAA. Percentage of bulblet regeneration ranged from $50.00 \pm 1.89$ to $100.00 \pm 0.00$. Maximum bulblet regeneration was noted on MS medium containing $0.0454 \mu \mathrm{M}$ TDZ - $10.74 \mu \mathrm{M}$ NAA, 0.06811 $\mu \mathrm{M}$ TDZ - 5.37 $\mu \mathrm{M}$ NAA and MS medium (control). Maximum number of $8.25 \pm 0.05$ bulblets per explant were noted on MS medium containing $0.0454 \mu \mathrm{M}$ TDZ $10.74 \mu \mathrm{M}$ NAA (Figure 1a). It was followed closely by $8.00 \pm 0.04$ bulblets per explant on $0.06811 \mu \mathrm{M}$ TDZ $2.685 \mu \mathrm{M}$ NAA. However, single bulblets were induced on MS medium (control). Bulblet diameter ranged from $0.10 \pm 0.001$ to $0.18 \pm 0.006 \mathrm{~cm}$. The largest bulbs were noted on MS medium containing $0.0454 \mu \mathrm{M}$ TDZ -10.74 $\mu \mathrm{M}$ NAA.

Table 1 Effects of various concentrations of TDZ-NAA on bulblet regeneration from twin scale explants of M.neglectum.

\begin{tabular}{|c|c|c|c|c|c|c|}
\hline \multicolumn{2}{|c|}{ Treatments } & \multirow{2}{*}{$\begin{array}{l}\text { Percentage }(\%) \\
\text { of bulb buds } \\
\text { induction* }\end{array}$} & \multirow{2}{*}{$\begin{array}{l}\text { Mean number of } \\
\text { bulb buds per } \\
\text { explant* }\end{array}$} & \multirow{2}{*}{$\begin{array}{l}\text { Percentage } \\
(\%) \text { of bulblet } \\
\text { regeneration* }\end{array}$} & \multirow{2}{*}{$\begin{array}{l}\text { Mean number } \\
\text { of bulblets per } \\
\text { explant* }\end{array}$} & \multirow{2}{*}{$\begin{array}{l}\text { Mean Number of } \\
\text { bulblets bulblet } \\
\text { diameter }(\mathrm{cm})^{\mathrm{ns}}\end{array}$} \\
\hline $\begin{array}{l}\text { TDZ } \\
(\mu \mathrm{M})\end{array}$ & $\begin{array}{l}\text { NAA } \\
(\mu \mathrm{M})\end{array}$ & & & & & \\
\hline 0.0454 & 2.685 & $16.67 \pm 0.08 \mathrm{a}$ & $1.15 \pm 0.01 \mathrm{~b}$ & $83.33 \pm 2.78 \mathrm{c}$ & $6.00 \pm 0.09 \mathrm{~b}$ & $0.13 \pm 0.004$ \\
\hline 0.0454 & 5.370 & $0.00 \pm 0.00 \mathrm{c}$ & $0.00 \pm 0.00 \mathrm{~d}$ & $75.00 \pm 3.12 \mathrm{~d}$ & $4.50 \pm 0.03 c$ & $0.15 \pm 0.005$ \\
\hline 0.0454 & 10.740 & $8.33 \pm 0.013 b$ & $0.58 \pm 0.06 \mathrm{c}$ & $100.00 \pm 0.00 \mathrm{a}$ & $8.25 \pm 0.05 \mathrm{a}$ & $0.18 \pm 0.006$ \\
\hline 0.06811 & 2.685 & $0.00 \pm 0.00 \mathrm{c}$ & $0.00 \pm 0.00 \mathrm{~d}$ & $50.00 \pm 1.89 \mathrm{e}$ & $8.00 \pm 0.04 a$ & $0.10 \pm 0.001$ \\
\hline 0.06811 & 5.370 & $16.67 \pm 0.07 \mathrm{a}$ & $1.18 \pm 0.05 b$ & $100.00 \pm 0.00 \mathrm{a}$ & $2.50 \pm 0.06 \mathrm{~d}$ & $0.13 \pm 0.005$ \\
\hline 0.06811 & 10.740 & $16.67 \pm 0.06 \mathrm{a}$ & $1.25 \pm 0.08 \mathrm{~b}$ & $91.67 \pm 4.39 \mathrm{ab}$ & $2.25 \pm 0.02 \mathrm{~d}$ & $0.10 \pm 0.006$ \\
\hline 0.0908 & 2.685 & $16.67 \pm 0.04 \mathrm{a}$ & $3.83 \pm 0.01 \mathrm{a}$ & $83.33 \pm 2.13 c$ & $2.00 \pm 0.04 \mathrm{~d}$ & $0.11 \pm 0.002$ \\
\hline 0.0908 & 5.370 & $0.00 \pm 0.00 \mathrm{c}$ & $0.00 \pm 0.00 \mathrm{~d}$ & $75.00 \pm 3.77 d$ & $6.00 \pm 0.07 \mathrm{~b}$ & $0.14 \pm 0.007$ \\
\hline 0.0908 & 10.740 & $0.00 \pm 0.00 \mathrm{c}$ & $0.00 \pm 0.00 \mathrm{~d}$ & $75.00 \pm 4.79 \mathrm{~d}$ & $5.42 \pm 0.06 \mathrm{~b}$ & $0.11 \pm 0.005$ \\
\hline \multicolumn{2}{|c|}{ Control (MS Medium) } & $0.00 \pm 0.00 \mathrm{c}$ & $0.00 \pm 0.00 \mathrm{~d}$ & $100.00 \pm 0.00 \mathrm{a}$ & $1.00 \pm 0.01 \mathrm{e}$ & $0.10 \pm 0.002$ \\
\hline
\end{tabular}


Table 2 Effects of various concentrations of TDZ-NAA on bulblet regeneration from bulblets regenerated on twin scale explants of M. Neglectum.

\begin{tabular}{|c|c|c|c|c|c|c|}
\hline \multicolumn{2}{|c|}{ Treatments } & \multirow{2}{*}{$\begin{array}{c}\text { Initial diameter } \\
\text { of bulblets } \\
(\mathrm{cm})^{*}\end{array}$} & \multirow{2}{*}{$\begin{array}{l}\text { Final diameter } \\
\text { of bulblets } \\
(\mathrm{cm})^{*}\end{array}$} & \multirow{2}{*}{$\begin{array}{l}\text { Diffference in } \\
\text { the bulblet } \\
\text { diameters }(\mathrm{cm})^{\mathrm{ns}}\end{array}$} & \multirow{2}{*}{$\begin{array}{l}\text { Axillary bulblet } \\
\text { regeneration } \\
\text { percentage }(\%)^{*}\end{array}$} & \multirow{2}{*}{$\begin{array}{l}\text { Mean number of } \\
\text { axillary bulblets } \\
\text { per explant* }\end{array}$} \\
\hline $\begin{array}{l}\text { TDZ } \\
(\mu \mathrm{M})\end{array}$ & $\begin{array}{l}\text { NAA } \\
(\mu \mathrm{M})\end{array}$ & & & & & \\
\hline 0.0454 & 2.685 & $0.29 \pm 0.03 \mathrm{ab}$ & $0.37 \pm 0.33 \mathrm{ab}$ & $0.08 \pm 0.004$ & $75.00 \pm 3.97 \mathrm{bc}$ & $1.25 \pm 0.04 \mathrm{~d}$ \\
\hline 0.0454 & 5.370 & $0.23 \pm 0.03 \mathrm{ab}$ & $0.35 \pm 0.09 \mathrm{ab}$ & $0.12 \pm 0.008$ & $91.67 \pm 4.38 \mathrm{ab}$ & $5.25 \pm 0.06 \mathrm{ab}$ \\
\hline 0.0454 & 10.740 & $0.23 \pm 0.07 \mathrm{ab}$ & $0.25 \pm 0.09 b$ & $0.02 \pm 0.005$ & $100.00 \pm 0.00 \mathrm{a}$ & $6.11 \pm 0.05 \mathrm{a}$ \\
\hline 0.06811 & 2.685 & $0.24 \pm 0.01 \mathrm{ab}$ & $0.48 \pm 0.04 \mathrm{a}$ & $0.23 \pm 0.003$ & $66.67 \pm 3.73 c$ & $1.50 \pm 0.5 \mathrm{~d}$ \\
\hline 0.06811 & 5.370 & $0.25 \pm 0.02 \mathrm{ab}$ & $0.44 \pm 0.03 \mathrm{ab}$ & $0.19 \pm 0.004$ & $83.33 \pm 4.36 b$ & $3.23 \pm 0.4 \mathrm{c}$ \\
\hline 0.06811 & 10.740 & $0.25 \pm 0.06 \mathrm{ab}$ & $0.48 \pm 0.03 \mathrm{a}$ & $0.23 \pm 0.008$ & $75.00 \pm 5.13 b c$ & $2.21 \pm 0.06 \mathrm{~d}$ \\
\hline 0.0908 & 2.685 & $0.28 \pm 0.3 \mathrm{ab}$ & $0.45 \pm 0.06 \mathrm{ab}$ & $0.17 \pm 0.007$ & $75.00 \pm 2.99 b c$ & $4.75 \pm 0.08 \mathrm{~b}$ \\
\hline 0.0908 & 5.370 & $0.31 \pm 0.08 \mathrm{ab}$ & $0.39 \pm 0.02 \mathrm{ab}$ & $0.08 \pm 0.009$ & $91.67 \pm 3.21 \mathrm{ab}$ & $5.00 \pm 0.09 \mathrm{ab}$ \\
\hline 0.0908 & 10.740 & $0.15 \pm 0.09 \mathrm{~b}$ & $0.31 \pm 0.01 \mathrm{ab}$ & $0.16 \pm 0.002$ & $50.00 \pm 2.96 \mathrm{~d}$ & $1.25 \pm 0.04 \mathrm{~d}$ \\
\hline \multicolumn{2}{|c|}{ Treatments } & & \multirow{2}{*}{\multicolumn{2}{|c|}{$\begin{array}{l}\text { Mean number of roots per explant } \\
\qquad(\%)^{*}\end{array}$}} & \multirow{2}{*}{$\begin{array}{l}\text { Mean number of } \\
\text { roots per explant }{ }^{\text {ns }}\end{array}$} & \multirow[b]{2}{*}{$\begin{array}{l}\text { Mean root length } \\
(\mathrm{cm})^{*}\end{array}$} \\
\hline $\begin{array}{l}\text { TDZ } \\
(\mu \mathrm{M}) \\
\end{array}$ & $\begin{array}{l}\text { NAA } \\
(\mu \mathrm{M})\end{array}$ & $\begin{array}{l}\text { Axillary bulblet } \\
\text { diameter }(\mathrm{cm})^{\text {ns }}\end{array}$ & & & & \\
\hline 0.0454 & 2.685 & $0.13 \pm 0.004$ & \multicolumn{2}{|c|}{$83.33 \pm 2.89 b$} & $2.75 \pm 0.09$ & $0.74 \pm 0.002 \mathrm{ab}$ \\
\hline 0.0454 & 5.370 & $0.10 \pm 0.009$ & \multicolumn{2}{|c|}{$83.33 \pm 3.62 b$} & $3.00 \pm 0.02$ & $0.87 \pm 0.009 \mathrm{ab}$ \\
\hline 0.0454 & 10.740 & $0.20 \pm 0.003$ & \multicolumn{2}{|c|}{$66.67 \pm 4.49 \mathrm{~d}$} & $4.38 \pm 0.06$ & $0.75 \pm 0.002 \mathrm{ab}$ \\
\hline 0.06811 & 2.685 & $0.10 \pm 0.004$ & \multicolumn{2}{|c|}{$91.67 \pm 2.10 \mathrm{ab}$} & $5.25 \pm 0.04$ & $1.62 \pm 0.008 \mathrm{a}$ \\
\hline 0.06811 & 5.370 & $0.10 \pm 0.009$ & \multicolumn{2}{|c|}{$75.00 \pm 5.18 \mathrm{bc}$} & $2.25 \pm 0.06$ & $0.85 \pm 0.009 \mathrm{ab}$ \\
\hline 0.06811 & 10.740 & $0.10 \pm 0.004$ & \multicolumn{2}{|c|}{$100.00 \pm 0.00 \mathrm{a}$} & $2.75 \pm 0.02$ & $0.57 \pm 0.009 \mathrm{ab}$ \\
\hline 0.0908 & 2.685 & $0.23 \pm 0.008$ & \multicolumn{2}{|c|}{$41.67 \pm 2.87 \mathrm{e}$} & $1.53 \pm 0.02$ & $0.83 \pm 0.001 \mathrm{ab}$ \\
\hline 0.0908 & 5.370 & $0.17 \pm 0.009$ & \multicolumn{2}{|c|}{$91.67 \pm 4.00 \mathrm{ab}$} & $4.58 \pm 0.04$ & $1.07 \pm 0.002 \mathrm{ab}$ \\
\hline 0.0908 & 10.740 & $0.10 \pm 0.005$ & \multicolumn{2}{|c|}{$66.67 \pm 5.40 \mathrm{~d}$} & $2.50 \pm 0.01$ & $0.31 \pm 0.002 b$ \\
\hline
\end{tabular}

${ }^{\text {ns }}$ non significant, \pm standard error, ${ }^{*}$ Means of values followed by different small letters are statistically different as calculated by Tukeys'b test at 0.05 level of significance.

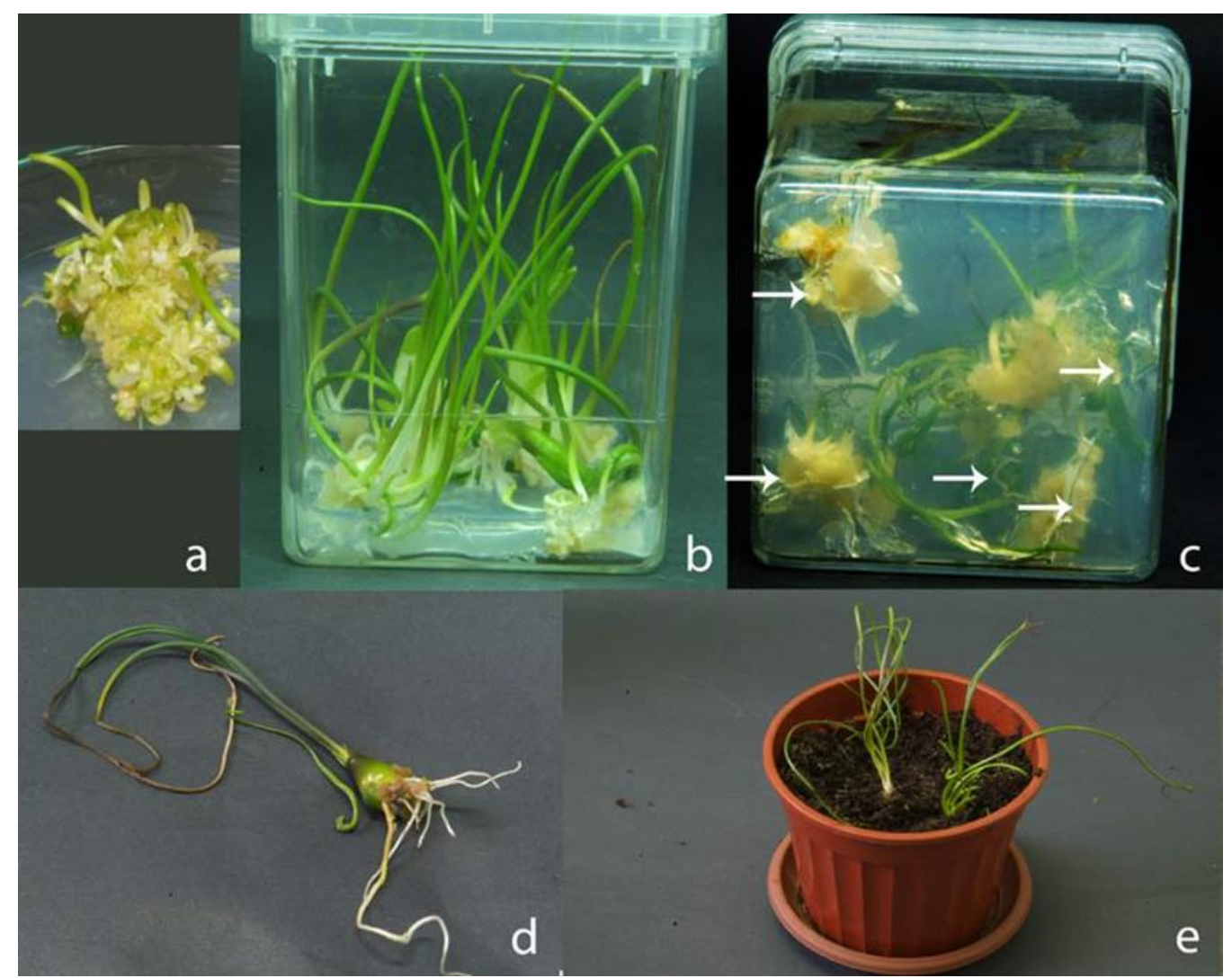

Figure 1 Effects of various concentrations of TDZ-NAA on bulblet regeneration from twin scale explants of M.neglectum. (a) Regeneration of bulblets after eight weeks on MS medium containing $0.0454 \mu \mathrm{M}$ TDZ - 10.74 $\mu \mathrm{M}$ NAA. (b-c) Regeneration on MS medium containing $0.0454 \mu \mathrm{M}$ TDZ - $10.74 \mu \mathrm{M}$ NAA showing regeneration of axillary bulblets and (d) roots. (e) Potting of rooted bulblets for acclimatisation. 


\section{Effect of TDZ-NAA Concentrations on Clonal Propagation of in vitro Regenerated}

\section{Bulblets Used as Explants}

The largest bulblets in the range of $0.15 \pm 0.09$ to 0.31 $\pm 0.08 \mathrm{~cm}$ were subcultured on MS medium containing different concentrations of TDZ-NAA (Table 2). They showed a variable increase in bulb diameters in the range of $0.25 \pm 0.09$ to $0.48 \pm 0.04 \mathrm{~cm}$ after another 8 weeks of culture. A comparison of initial and final bulb diameter noted a non-significant increase in their diameters in the range of 0.02 to $0.23 \mathrm{~cm}$. Maximum diameter of the bulblets was noted on MS medium containing 0.06811 $\mu \mathrm{M}$ TDZ - $19.74 \mu \mathrm{M}$ NAA (Figure 1d).

Axillary bulblet regeneration was noted on all mother bulblets in the range of $50.00 \pm 2.96$ to $100.00 \pm 0.00$. The number of axillary bulbs ranged from $1.25 \pm 0.04$ to $6.11 \pm 0.05$ bulblets per mother explant. Maximum number of axillary bulblets were noted on MS medium containing $0.0454 \mu \mathrm{M}$ TDZ - $10.74 \mu \mathrm{M}$ NAA (Figure $1 \mathrm{~b}$ and $\mathrm{c})$. The bulblet diameters increased in the range of $0.10 \pm 0.009$ to $0.23 \pm 0.008 \mathrm{~cm}$. After $2-3$ weeks of subculture, the mother bulbs began to develop root initials, which developed later into full length main roots. Mean rooting percentage ranged from $41.67 \pm 2.87$ to $100.00 \pm 0.00$. All bulblets showed rooting on MS medium containing $0.06811 \mu \mathrm{M}$ TDZ - $10.74 \mu \mathrm{M}$ NAA. The number of roots per mother explant and mean root length varied in the range of $1.53 \pm 0.02$ to $5.25 \pm 0.04$ and $0.31 \pm 0.002$ to $1.62 \pm 0.008 \mathrm{~cm}$, respectively. The bulblets attained sufficient diameter and roots; therefore, they were not further subcultured to improve rooting.

\section{Acclimatization of TDZ-NAA Regenerated Bulblets}

The acclimatized bulblets were transferred to pots containing compost, where these bulblets developed green leaves and continued the growth after acclimatisation, and were uprooted after eight weeks. Examination of the acclimatized bulblets after two months showed the replacement of in vitro regenerated roots by new thin and branched root apparatus with a reduction in the size of the potted bulblets. The bulblets took a period of about two weeks to acclimatize depending on the health and vegetative maturity of them, and the environmental conditions. All bublets regenerated on TDZ- NAA could be acclimatized (Figure $1 \mathrm{e}$ ).

\section{Discussion}

The species belonging to Muscari genus are famous for their uses as ornamental plants all over the world. Most of these are yet to be exploited for in vitro or ex vitro cultures under field conditions. Biotechnological approaches could serve as an easy alternative to the conservation of local germplasm in case there is an availability of a suitable protocol that could allow clonal propagation. The current study presents an efficient in vitro clonal propagation system of $M$. neglectum on MS medium containing variable concentrations of TDZ-NAA.

\section{Bulblet Regeneration Behaviour}

The twin scale explants behaved variably on MS medium containing different concentrations of TDZNAA. Comparison of regeneration on twin scale explants showed the maximum number of $8.25 \pm 0.05$ bulblets per explant on MS medium containing $0.0454 \mu \mathrm{M}$ TDZ $10.74 \mu \mathrm{M}$ NAA with a maximum bulblet diameter of 0.18 $\pm 0.006 \mathrm{~cm}$. The results of the study suggest that the indvidual regeneration on TDZ-NAA-containing MS medium was strongly influenced by the concentrations and combinations of plant growth regulators. The results are in agreement with Uranbey (2010 a, b), Uranbey et al. (2011), Ozel et al (2007, 2009, 2015), Vaziri et al. (2014) and Uzun et al. (2014), who reported the propagation of other Turkish Muscari species using different cytokinins and auxin concentrations.

The regeneration was directly related to the number of induced bulblet buds per explant. The results are in agreement with Hutchinson et al. (2004), who suggested a synergistic effect between -cytokinins and auxins in induction of shoots, roots and bulbsusing shoot tip explants of Ornithogalum saundersiae. Malabadi and Van Staden (2004), Mirici et al. (2005), Suh et al. (2005) and Uzun et al. (2014) also suggested beneficial effects of TDZ usage in combination with auxin(s) in regeneration of bulbous geophytes. Results of all studies suggested that type of explant has clear bearing and influence on the rate of regeneration and multiplication of the species that is micro propagated under in vitro conditions besides the plant growth medium, and the growth regulators used in the study.

\section{Bulblet Diameter}

The largest bulblets of $0.18 \pm 0.006 \mathrm{~cm}$ were recorded on MS medium containing $0.0454 \mu \mathrm{M}$ TDZ-10.74 $\mu \mathrm{M}$ NAA; however, when they were subcultured, the maximum increase in bulblet diameter on TDZ-NAA containing medium showed bulblets of similar size. TDZNAA had more synergistic effects on bulblet diameters. Moreover, TDZ-NAA were not toxic for M. neglectum without any carry over effect. High activity of TDZ-NAA has not been investigated in $M$. neglectum at the molecular level. It is assumed that TDZ-NAA has a synergic effect in a manner similar to Gill and Saxena's study (1992). They have suggested a crucial role of TDZ in the interaction with endogenous plant hormones that reprogram the mode of morphogenesis. This possibly acts by releasing, synthesising, protecting or even inhibiting auxins in situ in combination with other sub-cellular metabolic changes, in regulatory enzymes and related proteins. All (100\%) bulbs induced under in vitro conditions were easily acclimatised. However Uranbey et al. (2011) used 5-10 mm bulblets of M. azureum and acclimatised them on compost with a survival rate of $3 \%$. The possible reason could be different type of materials used for rooting. This experiment induced rooting under controlled in vitro conditions. Whereas, Uranbey et al. (2011) used compost instead to root the Muscari bulbs. It seems as if the Nitrogen rich compost had negative effect on the bulbs that most often results in burning of the plant material. 


\section{Rooting}

Comparing different concentrations of TDZ-NAA in MS medium on induction of the roots, a negligible carry over effect of these concentrations was noted. All of the induced bulblets did not need a separate rooting medium. The bulblets behaved variably in terms of root mean number and root length. It was also noted that MS medium (control) used singly was ineffective to induce roots. These results are not in agreement with Uranbey (2010a,b), Uranbey et al. (2010), Vaziri et al. (2014), Ozel et al. (2007, 2009, 2015) and Uzun et al (2014)'s studies. The authors used either NAA or IBA for the rooting of different species of Muscari. These results are in agreement with the results reported by Ozel et al. (2009), who had almost similar observation on rooting of Muscari macrocarpum.

\section{Number of Roots}

Considering the number of roots per explant and their length on the bulblets regenerated on MS medium containing different concentrations of TDZ-NAA, the longest and maximum number of roots were noted on $0.0454 \mu \mathrm{M}$ TDZ - $10.74 \mu \mathrm{M}$ NAA containing MS medium. These bulblets were acclimatized in the growth chamber. It is assumed that synergetic effect of TDZNAA in interaction with endogenous plant hormones and other sub-cellular metabolic changes played a key role in the elongation of roots in agreement with the observations of Alizadeh et al. (2013) in Allium tuberosum.

\section{Acclimization}

The acclimatized bulblets were transferred to pots containing leaf compost and were uprooted after eight weeks. The initial fragile thick root structure of the acclimatized bulblets was replaced by much more supportive longer and multi-branched secondary roots which is in agreement with resulted of Ozel and Khawar (2007) at the end of the experiment. Khawar et al. (2005) and Ozel et al. (2009) emphasize that transplantation of bulblets from in vitro to ex vitro conditions needs some period for acclimatization that could end up with variable number of survival of in vitro regenerated bulblets depending on bulblets health, their vegetative maturity and prevailing environmental conditions. Ozel et al. (2009) acclimatized $M$. macrocapum bulblets in the growth chamber at constant temperature of $24 \pm 1^{\circ} \mathrm{C}$. Similarly, Wang et al. (2013) acclimatized $M$. armeniacum on perlite and torf (1:3) mixture for 4 weeks. On the other hand, Uzun et al (2014) induced $100 \%$ acclimatization of Muscari muscarimi in peat moss, vermiculite and perlite (1:1:1) mixture. Uranbey et al. (2011) used 5-10 $\mathrm{mm}$ bulblets of $M$. azureum and acclimatized them on compost with a survival rate of $3 \%$. The possible reason for this observation could be the difference in genotypes, cultural conditions and type of composts that were used in two experiments during acclimatisation.

\section{Regeneration of New Roots}

New roots were induced on all bulbs after they were transferred to soil. Replacement of in vitro regenerated roots by new thin and branched roots in the soil is a positive factor suggesting that the bulblets could induce root initials in the soil, once they find appropriate environment. This suggests that the bulblets need an appropriate vegetative growth stage to induce roots in the soil. Similar observations were recorded in Ornithogalum oligophyllum (Ozel and Khawar, 2007) and Muscari macrocarpum (Ozel et al., 2009).

No problem was noted in the acclimatisation in compliance to the findings of O'Connor et al. (2007), who observed that the explants with high number of short and stout roots were more likely to survive acclimatisation. They suggested that small, healthy and strong rooted bulblets were easily acclimatised with minimum damage to roots.

\section{Conclusion}

This study provided an important addition to the literature on microclonal propagation of M. neglectum. Use of auxins for root induction was not needed separately. TDZ induced faster induction of physiologic age on the bulblets that influenced rooting positively. It meets the objective of the study and provides a good information about the potential growth regulator combinations for bulblet regeneration from twin scale explants of M. Neglectum. The results suggest potentiality of this protocol for commercial propagation.

\section{References}

Alizadeh B, Royandazagh SD, Khawar KM, Ozcan S. 2013. Micropropagation of garlic chives (Allium tuberosum Rottl. Ex Sprang) using mesocotyl axis. J. Anim. Plant Sci.23(2): 543545.

Davis PH, Stuart DC. 1984. Muscari Miller. pp. 245-263 in Davis, P.H. (Ed.) Flora of Turkey and the East Aegean Islands. Vol. 8. Edinburgh, Edinburgh University Press.

Doussi MA, Thanos CA. 2002. Ecophysiology of seed germination in Mediterranean geophytes. 1. Muscari spp. Seed Sci. Res. 12: 193-201.

Gill R, Saxena PK. 1992. Direct somatic embryogenesis andregeneration of plant from seedling explant of peanut (Arachishypogae L): Promotive role of thidiazuron. Can. J. Botany. 70: 1186-1192.

Hutchinson MJR, Onamu R, Obukosia SD. 2004. In vitro Propagation of Ornithogalum saundersiae: potential of Thidiazuronas a chemical of choice. J. Agric. Sci. Technol. 6(1): 60-68.

Jaime A, Teixeira da S, Judit DN. 2016. Tissue culture of Muscari species: present achievements and future perspectives. Rend. Fis. Acc. Lincei DOI 10.1007/s12210-016- -0505-y

Karamian R, Sharifzadeh A, Ranjbar M. 2011. Evidence of somatic embryogenesis for plantlet regeneration in Muscari neglectum Guss. Afr. J. Agric. Res. 6(14): 3247-3251.

Khawar KM, Cocu S, Parmaksiz I, Sarihan EO, Sancak C, Ozcan S. 2005. Mass proliferation of Madona Lilly (Lilium candidum L.) under in vitro conditions. Pak. J. Bot. 37: 243-248.

Lim TK. 2014. Muscari neglectum. In: Edible medicinal and nonmedicinal plants. Springer Science Business Media, Dordrecht, pp 122-125. 
Malabadi RB, Van Staden J. 2004. Regeneration of Ornithogalum in vitro. S. Afr. J. Bot.70: 618-621.

Mirici S, Parmaksiz I, Ozcan S, Sancak C, Uranbey S, Sarihan E, Gumuscu A,Gurbuz B, Arslan N. 2005. Efficient in vitro bulblet regeneration from immature embryos of endangered Sternbergia fischeriana. Plant Cell Tis. Org. 80: 239-246.

Moris S, Nakano M. 2004. Somatic embryo induction from leaf-and flower bud-derivied calli in several Muscari species and cultivars. Propag. Ornam. Plants. 4: 58-62.

Murashige T, Skoog F. 1962. A revised medium for rapid growth and bioassays with 277 tobacco cultures. Physiology Plantarum. 15: 473-497.

Nakano M, Tanaka S, Kakami S, Saito H. 2005. Plantlet regeneration from protoplasts of Muscari armeniacum Leichtl Ex Bak. Plant Biotechnol. 22: 249-251.

Nasrabadi M, Halimi M, Nadaf M. 2013. Phtochemical screening and chemical composition of extract of M. neglectum. MiddleEast J. Sci.Res. 14(4): 566-569.

O'Connor CAB, Hubstenberger J, Killough C, VanLeeuwen DM, Hilaire RS. 2007. In vitro propagation of Acer grandidentatum Nutt. In vitro Cell Dev. Bot. 43(1): 40-50.

Ozel CA, Khawar KM. 2007. In vitro bulblet regeneration of Ornithogalum oligophyllum E. D. Clarke using twin scale bulb explants. Propag. Ornam. Plants. 2: 82-88.

Ozel CA, Khawar KM, Arslan O, Unal F. 2009. In vitro propagation of the Golden grape hyacinth (Muscari macrocarpum sweet) from twin scale explant. Propag. Ornam. Plants. 9: 169-175.

Ozel CA, Khawar KM, Unal F. 2015. Factors affecting efficient in vitro micropropagation of Muscari muscarimi Medikus using twin bulb scale. Saudi J. Biol. Sci. 22: 132-138.

Saniewski M, Pytlewski C. 1979. Regeneration of plantlets on leaves and inflorescence stalk of Muscari through tissue culture. Bull. Pol. Acad. Sci. 27: 519-521.
Snedecor GW, Cochran WG. 1967. Statistical Methods. The Iowa State Univ. Press, Iowa. USA. P. 327-329.

Suh J, Lee W, Lee A. 2005. New plantlet proliferation and bulbing promotion in vitro cultures of Ornithogalum hybrid. Acta Hortic. 683: 155-163.

Uranbey S. 2010a In vitro bulblet regeneration from immature embryos of Muscari azureum. Afr. J. Biotechnol. 9(32): 51215125.

Uranbey S. 2010b. Stimulating effects of different basal media and cytokinine types on regeneration of endemic and endangered Muscari aucheri. Arch. Biol. Sci. 62(3): 663-667/669.

Uranbey S, Ipek A, Caliskan M, Dundar E, Cocu S, Basalma D, Guneylioglu H. 2011. In vitro bulblet induction from bulb scales of endangered ornamental plant Muscari azureum. Biotechnol. Biotec. Eq. 24(2):1843-1848.

Usher G. 1974. A dictionary of plants used by man. 619 Seiten. Constable and Company Ltd., London.

Uzun S, Parmaksiz I', Uranbey S, Mirici S, Sarihan EO, Ipek A, Kaya MD, Gurbuz B, Arslan N, Sancak C, Khawar KM, Ozcan S. 2014. In vitro micropropagation from immature embryos of the endemic and endangered Muscari muscarimi Medik. Turk. J. Biol. 38: 83-88.

Vaziri PA, Uranbey S, Sancak C. 2014. Efficient in vitro microprapagation for the conservation of endemic and endangered aucher-eloy grape hyacinth [Muscari Aucheri (boiss.) Baker].J. Appl. Biol. Sci. 8(1): 80-83

Wang S, Yang FM, Jiu LJ, Zhang W, Zhang W, Tian ZG, Wang F. 2013. Plant regeneration via somatic embryogenesis from leaf explants of Muscari armeniacum. Biotechnol. Biotec. Eq. 27(6): 4243-4247. 